\title{
Carbon accumulation in the red clay layer of the subsoil in a major river delta: Contribution of secondary carbonate
}

\author{
Yuan $\mathrm{Li}^{\mathrm{a}}{ }^{\mathrm{b}}$, Chuancheng Fu, ${ }^{\mathrm{a}}$, Lin Zeng ${ }^{\mathrm{d}}$, Qian Zhou ${ }^{\mathrm{a}}$, Haibo Zhang ${ }^{\mathrm{e}}$, Chen $\mathrm{Tu}^{\mathrm{a}, \mathrm{b}}$, Jing Wei ${ }^{\mathrm{a}, \mathrm{b}}$, \\ Lianzhen $\mathrm{Li}^{\mathrm{a}}{ }^{\mathrm{a} b}$, Yongming Luo ${ }^{\mathrm{a}, \mathrm{b}, \mathrm{c}, *}$ \\ ${ }^{a}$ Key Laboratory of Coastal Environmental Processes and Ecological Remediation, Yantai Institute of Coastal Zone Research, Chinese Academy of Sciences, Yantai 264003, \\ PR China \\ ${ }^{\mathrm{b}}$ Center for Ocean Mega-Science, Chinese Academy of Sciences, Qingdao 266071, PR China \\ ${ }^{\mathrm{c}}$ Institute of Soil Science, Chinese Academy of Sciences, Nanjing 210008, PR China \\ ${ }^{\mathrm{d}}$ School of Resources and Environmental Engineering, Ludong University, Yantai 264025, PR China \\ ${ }^{\mathrm{e}}$ Key Laboratory of Soil Contamination Bioremediation of Zhejiang Province, School of Environmental \& Resource Sciences, Zhejiang Agriculture and Forestry University, \\ Hangzhou 311300, PR China
}

\section{A R T I C L E I N F O}

\section{Keywords:}

Carbon stabilization

Secondary carbonate

Clay layer

Subsoil

Yellow River

\begin{abstract}
A B S T R A C T
Understanding $\mathrm{C}$ formation and budgets in soils of large river deltas is necessary in studying the global C cycle because deltas are important interfaces between continents and oceans for material fluxes. Soil organic carbon (SOC) and soil inorganic carbon (SIC) were assessed at different soil depths in wetlands and farmland of the Yellow River Delta. SOC content decreased by $54 \%$ in the topsoil after converting wetland to farmland and there was little soil inorganic carbon (SIC enrichment). However, the contents and stocks of SOC and SIC in the subsoil were significantly enhanced in the red clay layer (RCL) in both land use types. The RCL also showed high accumulation rates of SIC (197 $\left.\pm 95 \mathrm{~g} \mathrm{C} \mathrm{m}^{-2} \mathrm{yr}^{-1}\right)$, highlighting its importance in carbon sequestration in this large estuary. A negative correlation between SIC and $\delta^{13} \mathrm{C}_{\mathrm{SIC}}$ throughout the dataset and more negative values in the RCL indicate a larger contribution of secondary carbonate under C3 vegetation in the RCL. A positive correlation between SIC and SOC suggests that an enhancement of SOC may lead to an increase in SIC, especially in the subsoil YSL-RCL sequence with its relatively low SOC content. The RCL formed in the fluvial-deltaic sedimentary system with both higher carbonate content and stronger weathering intensity indicates that adsorption and precipitation of atmospheric derived carbonate on fine-grained suspended particulates may be important factors in carbonate accumulation.
\end{abstract}

\section{Introduction}

Soils with $2470 \mathrm{Pg}\left(1 \mathrm{Pg}=10^{15} \mathrm{~g}\right)$ carbon $(\mathrm{C})$ hold the largest terrestrial pool of $\mathrm{C}$ and contain both organic and inorganic $\mathrm{C}$ (Eswaran et al., 2000; Lal, 2004). Globally, soil organic carbon (SOC) amounts to $697 \mathrm{Pg} \mathrm{C}$ at $0-30 \mathrm{~cm}$ depth and $1500 \mathrm{Pg} \mathrm{C}$ at $0-100 \mathrm{~cm}$ (Eswaran et al., 2000). Soil inorganic carbon (SIC) storage reaches $160 \mathrm{Pg} \mathrm{C}$ at 0-30 cm (Nieder and Benbi, 2008) and from 695 to $748 \mathrm{Pg} \mathrm{C}$ (Batjes, 1996) to $1738 \mathrm{Pg}$ C (Eswaran et al., 1995) at 0-100 cm depth. More than $50 \%$ of SOC and $70 \%$ of SIC are stored in the subsoil. Subsoil C may be even more important than topsoil $\mathrm{C}$ in terms of sources or sinks for $\mathrm{CO}_{2}$, particularly in arid and semi-arid inland and coastal regions where SIC stocks are approximately 1-9 times higher than SOC stocks and a large amount of SIC with a faster accumulation rate than SOC is stored in the subsoil (Lal and Kimble, 2000; Scharpenseel et al., 2000; Mi et al., 2008; Wang et al., 2015; Saderne et al., 2018).

SIC can be categorized into two main groups, namely primary and secondary carbonates. Primary carbonate is inherited from soil parent materials such as limestone particles. Secondary carbonate originates during soil formation from former carbonate or $\mathrm{Ca} / \mathrm{Mg}$-silicate minerals. The former obtains $\mathrm{Ca}$ from the dissolution and re-precipitation of pre-existing carbonate, commonly primary carbonate, which has no net $\mathrm{C}$ sequestration, whereas the latter obtains $\mathrm{Ca}$ from silicate minerals (e.g., Ca silicates weathering, fertilizers or irrigation water containing $\mathrm{Ca}^{2+}$ and $\mathrm{Mg}^{2+}$ bearing salts) and contributes to net $\mathrm{C}$ sequestration as follows (Monger et al., 2015).

$2 \mathrm{CO}_{2}+3 \mathrm{H}_{2} \mathrm{O}+\mathrm{CaSiO}_{3} \rightarrow \mathrm{Ca}_{2}^{+}+2 \mathrm{HCO}_{3}+\mathrm{H}_{4} \mathrm{SiO}_{4}$

\footnotetext{
* Corresponding author at: Key Laboratory of Coastal Environmental Processes and Ecological Remediation, Yantai Institute of Coastal Zone Research, Chinese Academy of Sciences, Yantai 264003, PR China.

E-mail address: ymluo@yic.ac.cn (Y. Luo).
} 
$\mathrm{Ca}^{2+}+2 \mathrm{HCO}_{3}{ }^{-} \rightarrow \mathrm{CaCO}_{3}+\mathrm{CO}_{2}+\mathrm{H}_{2} \mathrm{O}$

Secondary carbonate can be formed in situ and ex situ. In-situ secondary carbonate is more common but ex-situ secondary carbonate also exists, especially in source to sink systems where the chemical weathering of river sediment during transfer through the floodplains may result in a flux of $\mathrm{CO}_{2}$ uptake (Bouchez et al., 2012; Frings et al., 2015). SIC also links SOC with short residence times to the long-term geological C cycle (Liu et al., 2010). Several studies report SIC enhancement through the formation of secondary carbonate under long-term application of organic fertilizers and/or irrigation in arid and semi-arid inland regions usually with alkaline $\mathrm{pH}(>8)$ and rich in $\mathrm{Ca}$ and/or $\mathrm{Mg}$ (>0.1\%) (Landi et al., 2003; Wang et al., 2014, 2015; Bughio et al., 2016).

Recent studies show that coastal ecosystems dominated by plants play a critical role in the global sequestration of organic $\mathrm{C}$, in part because of their high efficiency in trapping sediment and associated organic C (McLeod et al., 2011). However, organic C often only represents a small portion of trapped sediments and/or coastal soils (globally $\sim 2-3 \%$ ) whereas mineral and siliciclastic deposits and carbonate contribute about $50-98 \%$ of the sediments and/or soils (Kristensen et al., 2008; Macreadie et al., 2013). Mazarrasa et al. (2015) estimated that the global mean inorganic $\mathrm{C}$ accumulation rate in seagrass meadows reached $126.3 \pm 31.05 \mathrm{~g} \mathrm{C} \mathrm{m}^{-2} \mathrm{yr}^{-1}$. Saderne et al. (2018) calculated that the mean inorganic $C$ accumulation rate in coastal vegetated ecosystems of the Arabian Gulf, representing hotspots of carbonate production, was about $148 \pm 63 \mathrm{~g} \mathrm{C} \mathrm{m}^{-2} \mathrm{yr}^{-1}$ over the last decades/century. These high rates of carbonate accumulation imply that coastal vegetated ecosystems are strong $\mathrm{CO}_{2}$ sinks. The contribution of carbonate to soil accretion is also key in supporting seabed elevation to keep pace with sea level rise in arid and semiarid tropical areas (Saderne et al., 2018).

River deltas are source to sink sedimentary systems, serving as important sites of carbon transfer between terrestrial and marine reservoirs (Bianchi and Allison 2009). The global riverine flux of terrestrial $\mathrm{C}$ to the ocean is $\sim 0.9 \mathrm{Pg} \mathrm{yr}^{-1}$ and half of this $\mathrm{C}$ is inorganic $\mathrm{C}$ (Cole et al., 2007). The riverine $C$ will go through deposition, burial and transformation in delta systems before entering coastal oceans (Bauer et al., 2013). This calls for investigation of SIC stocks, forms and accumulation rates to understand the role of SIC in the C cycle in delta systems, as well as the link with SOC. The Yellow River ranks first or second in the world in terms of sediment load with an annual average of 1.1 Pg (Milliman and Syvitski 1992). The Yellow River transported $6.28 \times 10^{11} \mathrm{~g}$ dissolved inorganic C (DIC) into the Bohai Sea in 2014, 17 times higher than the DOC fluxes (Wang et al., 2016). In our previous study (Li et al., 2019), we found a red clay layer (RCL) with a thickness of $5-50 \mathrm{~cm}$ at $1 \mathrm{~m}$ depth in the soil profile broadly distributed in the YRD. The clay-enriched subsurface layer is one of the important features of loess-derived soils (Gunal and Ransom, 2006; Khormali et al., 2012; Bockheim and Hartemink, 2013). To our knowledge, assessments of the forms and budgets of SIC and its relationship with SOC at different soil depths in large river deltas considering source to sink relationships have yet to be reported.

Here, we present carbon isotopic $\left(\delta^{13} \mathrm{C}\right)$, magnetic (anhysteretic remanent magnetization $\left(\chi_{\text {ARM }}\right)$ /saturated isothermal remanent magnetization (SIRM)) and sedimentary $\left({ }^{210} \mathrm{~Pb}\right.$ mass accumulation rate) studies of SIC and SOC in the YRD. Our objectives are (1) to quantify SIC and SOC pools in distinct soil layers under different land use types and (2) to identify the contribution of secondary carbonate.

\section{Materials and methods}

\subsection{Site description}

The Yellow River, which has historically transported about $10^{9} \mathrm{t}$ $\mathrm{yr}^{-1}$ of sediment from the erosion of Loess Plateau in central China
(Milliman and Syvitski, 1992), has been discharging into the western Bohai Sea since 1855 and forming the modern Yellow River Delta (YRD) with a land area of $5000 \mathrm{~km}^{2}$ (Pang and Si, 1979). The soil in the YRD is also a loess-like sediment due to nearly $90 \%$ of the river sediment being sourced from the Chinese Loess Plateau (CLP) (Wang et al., 2015). Rapid deposition of the suspended sediment has shifted the deltaic river channel a total of 11 times, resulting in the formation of different sedimentary successions. The sedimentary successions in the YRD are characterized by cyclic changes in clay-enriched layers and silt-enriched layers which are likely due to hydrodynamic sorting, provenance change and post-depositional alteration (Xue et al., 1995; Saito et al., 2000; Li et al., 2019).

The YRD is unique in its dynamic, ecological and economic characters, characterized as one of the most rapid sedimentation areas in the world and including the most integrated estuary wetland ecosystem with important agricultural production and the second-largest oil production basin (Shengli oilfield) in China. A large portion of coastal wetland has been converted into agricultural land (Han et al., 2014).

\subsection{Soil sampling}

Forty-two soil profiles (Y01-Y42), fifteen cores (Y45-Y54, Y58-Y62) and five high resolution soil profiles (Y07, Y09, Y16, Y23, Y53) were collected in our previous studies for RCL identification (Fig. 1a) (Li et al., 2018, 2019). Profiles $1 \mathrm{~m}$ in depth were sampled according to diagnostic layers from bottom to top. The number of layers and the position of each were based on attributes observed in the field such as morphological soil properties. All soil samples were collected using a stainless-steel hand auger and then transferred to polyethylene bags. High resolution soil profiles were sampled at an interval of $5 \mathrm{~cm}$ at $170 \mathrm{~cm}$ depth (Y16) and $120 \mathrm{~cm}$ depth (Y23) from the groundwater table to the surface. Samples from thin or discontinuous layers were added to the layer above or below. According to the diagnostic characteristics, soil layers were integrated into the surface layer (SL, 0-20 cm), red clay layer (RCL) and its upper and lower yellow silt layers (YSL, UYSL, LYSL) (Fig. 1b). Previous studies show that a RCL with similar geochemical features is widely distributed in the YRD (Li et al., 2019). In the present study four typical soil profiles from wetland (Y05, Y07, Y12, Y23) and farmland (Y04, Y08, Y14, Y16) as comparison and two high resolution profiles (Y23 and Y16) were selected to investigate the variations in carbon of the YSL-RCL sequence. The numbers and classifications of soil layer samples of typical soil profiles are shown in Table S1 in the supporting materials.

\subsection{Sample analysis}

Soil samples were air dried and passed through a 2-mm screen for determination of $\mathrm{pH}$, salinity, soil grain size and ${ }^{210} \mathrm{~Pb}$ activity. Representative subsamples were then ground to $0.149 \mathrm{~mm}$ for determination of $\mathrm{C}$ contents, isotopic values and magnetic properties.

Bulk density was determined by coating clod fragments from each layer with a cutting ring. Soil $\mathrm{pH}$ and salinity were determined using 1:2.5 and 1:5 (w/v) soil:water mixtures, respectively. Soil grain size was determined using a Malvern Mastersizer 2000 instrument after removing organic matter and carbonates using $15 \% \mathrm{H}_{2} \mathrm{O}_{2}$ and $1 \mathrm{M} \mathrm{HCl}$, and then dispersal in $0.05 \mathrm{M}$ sodium hexametaphosphate solution overnight followed by ultrasonic treatment for $30 \mathrm{~min}$.

$\mathrm{A}^{210} \mathrm{~Pb}$ technique was used to calculate the mass accumulation rate (MAR) in the YRD due to the formation of the soil by deposition of the Yellow River sediment and it appears as a loess-like sediment. Determination of ${ }^{210} \mathrm{~Pb}$ activities of the high-resolution soil profile samples was conducted using an EG \& G Ortec HPGe GWL gamma-ray spectrometer (Ametek Inc., Berwyn, PA). The total ${ }^{210} \mathrm{~Pb}$ and ${ }^{226} \mathrm{Ra}$ activities were measured at $46.5 \mathrm{keV}$ and $295.2 \mathrm{keV}\left({ }^{214} \mathrm{~Pb}\right)$, respectively. Excess ${ }^{210} \mathrm{~Pb}\left({ }^{210} \mathrm{~Pb}_{\mathrm{ex}}\right)$ was calculated by subtracting ${ }^{226} \mathrm{Ra}$ activity from total ${ }^{210} \mathrm{~Pb}$ activity. The profile distribution of ${ }^{210} \mathrm{~Pb}_{\mathrm{ex}}$ 

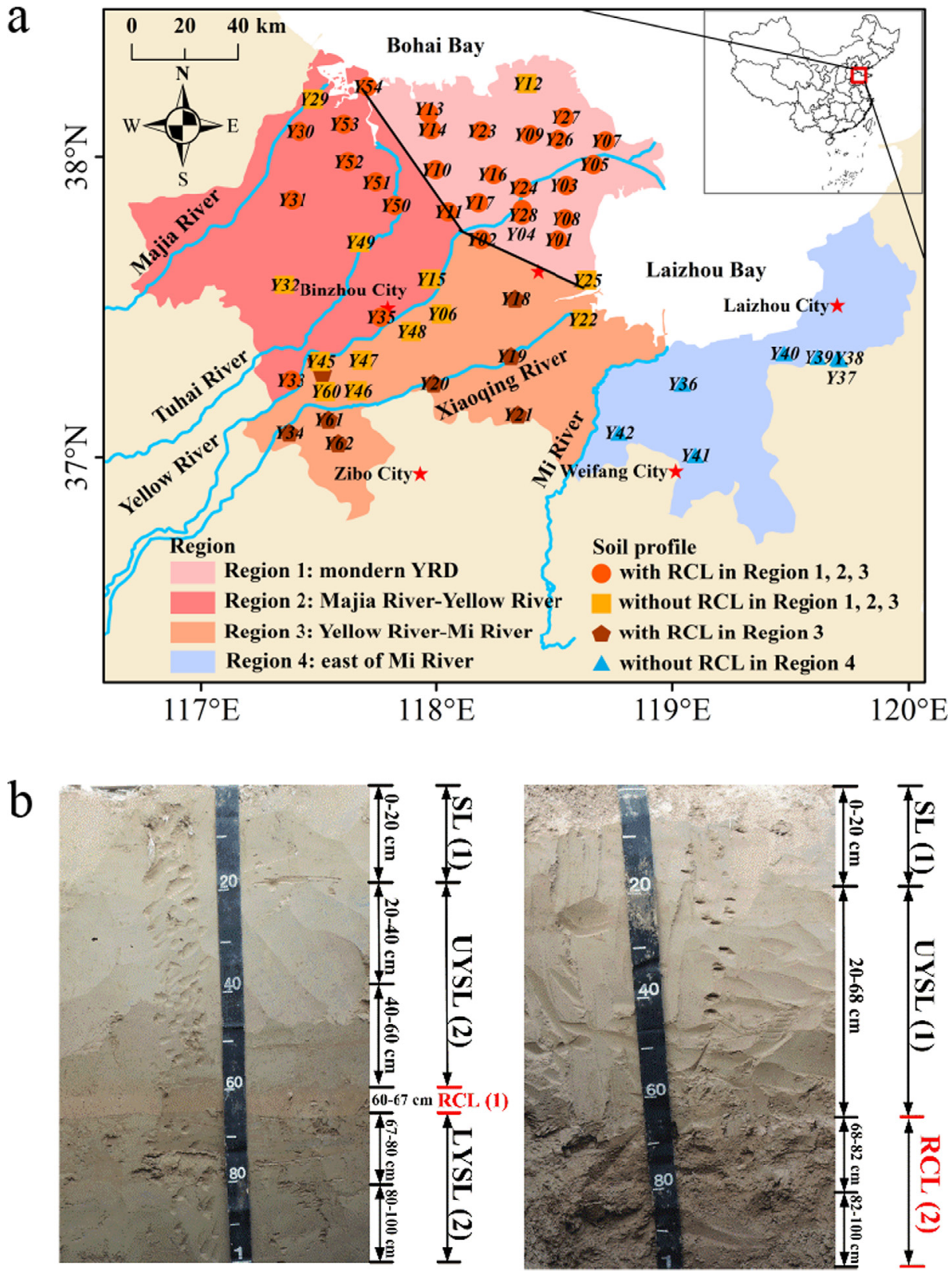

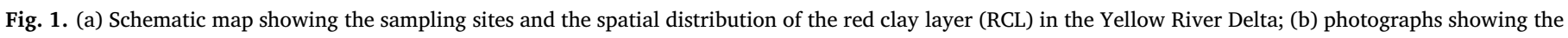


cations of soil layer samples are presented in Table S1 in the supporting materials.

activities is shown in Fig. S1 in the supporting materials. The constant rate of supply (CRS) model was used for the determination of MAR (Sanchez-Cabeza and Ruiz-Fernández, 2012). The top $20 \mathrm{~cm}$ of the high-resolution profile was removed from the calculation to avoid topsoil disturbance.

Total carbon (TC) and SOC were determined using a Vario MACRO cube elemental analyzer (Elementar, Langenselbold, Germany). SOC was determined by pretreating soil samples with $1 \mathrm{M} \mathrm{HCl}$ to remove carbonates. SIC was calculated as the difference between TC and SOC. SOC and SIC stocks were calculated from carbon contents and bulk densities. For ${ }^{13} \mathrm{C}$ in $\mathrm{SOC}, \mathrm{CO}_{2}$ was collected in the same way as that for SOC. For ${ }^{13} \mathrm{C}$ in SIC, $\mathrm{CO}_{2}$ was collected from a vacuum system where soil samples were reacted with $100 \% \mathrm{H}_{3} \mathrm{PO}_{4}$ for $3 \mathrm{~h}$ at $70{ }^{\circ} \mathrm{C}$. The $\mathrm{CO}_{2}$ collected was then subjected to isotopic analysis using a Thermo MAT253 mass spectrometer (continuous flow mode). $\delta^{13} \mathrm{C}$ is expressed relative to the international standard of PDB. Replication gave a standard deviation better than $\pm 0.1 \%$ based on repeated measurements of the international standards IAEA-600, NBS-18 and IAEA-CO-8. Reproducibility of sample replicates was generally better than $\pm 0.2 \%$ for $\delta^{13} \mathrm{C}$.

For magnetic properties, $\chi_{\text {ARM }}$ was acquired in a peak alternating field of $100 \mathrm{mT}$ with a bias field of $0.04 \mathrm{mT}$ using a Dtech 2000 demagnetizer. SIRM was acquired using a forward field of $1 \mathrm{~T}$ using a MMPM10 pulse magnetizer.

\subsection{Statistical analysis}

Statistical analysis was performed using the SPSS 20.0 for Windows software package (SPSS Inc., Chicago, IL). One-way analysis of variance (ANOVA) was used to test the differences among the four soil layers described above. Pearson correlation analysis was conducted to detect relationships among the variables investigated. 
Table 1

Main soil properties at different soil depths of wetland and farmland in the Yellow River Delta.

\begin{tabular}{|c|c|c|c|c|c|c|c|c|}
\hline \multirow[t]{2}{*}{ Soil property } & \multicolumn{4}{|l|}{ Wetland } & \multicolumn{4}{|l|}{ Farmland } \\
\hline & SL & UYSL & RCL & LYSL & SL & UYSL & RCL & LYSL \\
\hline $\mathrm{pH}$ & $8.35(0.52) \mathrm{a}$ & $8.42(0.44) \mathrm{a}$ & $8.27(0.13) \mathrm{a}$ & $8.42(0.17) \mathrm{a}$ & $8.28(0.24) \mathrm{a}$ & $8.37(0.21) \mathrm{a}$ & $8.35(0.22) \mathrm{a}$ & $8.34(0.15) \mathrm{a}$ \\
\hline Salinity $\left(\mathrm{g} \mathrm{kg}^{-1}\right)$ & $9.69(5.37) \mathrm{a}$ & $6.92(1.83) \mathrm{ab}$ & $8.39(2.20) \mathrm{a}$ & $7.56(1.22) \mathrm{ab}$ & $2.13(1.85) \mathrm{b}$ & $4.64(4.10) \mathrm{ab}$ & $5.86(5.62) \mathrm{ab}$ & $5.91(2.51) \mathrm{ab}$ \\
\hline $\mathrm{BD}\left(\mathrm{g} \mathrm{cm}^{-3}\right)$ & $1.35(0.11) \mathrm{ab}$ & $1.44(0.03) \mathrm{a}$ & $1.23(0.09) \mathrm{b}$ & $1.47(0.04) \mathrm{a}$ & $1.39(0.12) \mathrm{a}$ & $1.41(0.07) \mathrm{a}$ & $1.36(0.11) \mathrm{a}$ & $1.45(0.04) \mathrm{a}$ \\
\hline Clay $(\%)$ & $6.19(2.57) \mathrm{a}$ & $3.24(0.52) \mathrm{a}$ & $16.9(6.3) \mathrm{b}$ & $3.83(0.11) \mathrm{a}$ & $5.32(1.26) \mathrm{a}$ & $4.02(2.03) \mathrm{a}$ & $13.7(5.26) \mathrm{b}$ & $4.45(2.01) \mathrm{a}$ \\
\hline Silt (\%) & $32.6(17.3) \mathrm{a}$ & $18.0(8.1) \mathrm{a}$ & $66.6(11.3) \mathrm{b}$ & $15.1(4.5) \mathrm{a}$ & $18.1(6.9) \mathrm{a}$ & $19.9(17.2) \mathrm{a}$ & $61.9(15.3) \mathrm{b}$ & $27.2(21.2) \mathrm{a}$ \\
\hline Sand $(\%)$ & $61.2(19.8) \mathrm{a}$ & $78.7(5.8)$ a & $16.5(16.4) \mathrm{b}$ & $81.1(4.6) \mathrm{a}$ & $76.6(7.8) \mathrm{a}$ & $76.1(19.2) \mathrm{a}$ & $24.5(19.3) \mathrm{b}$ & $68.3(23.2) \mathrm{a}$ \\
\hline$\chi_{\mathrm{ARM}} / \operatorname{SIRM}\left(10^{-5} \mathrm{~m} \mathrm{~A}^{-1}\right)$ & $23.1(4.5) \mathrm{a}$ & $22.7(1.7) \mathrm{a}$ & $64.4(12.8) \mathrm{b}$ & $20.4(2.4) \mathrm{a}$ & $23.7(5.3) \mathrm{a}$ & $21.8(6.0) \mathrm{a}$ & $61.4(12.0) \mathrm{b}$ & $24.5(6.9) \mathrm{a}$ \\
\hline$\delta^{13} \mathrm{C}_{\text {SOC }}(\%)$ & $-24.7(1.44) \mathrm{a}$ & $-22.4(0.3) \mathrm{b}$ & $-22.9(0.2) \mathrm{ab}$ & $-22.5(0.2) \mathrm{b}$ & $-23.5(0.4) \mathrm{b}$ & $-22.0(0.6) \mathrm{b}$ & $-22.2(0.3) \mathrm{b}$ & $-22.4(0.3) \mathrm{b}$ \\
\hline$\delta^{13} \mathrm{C}_{\text {SIC }}(\%)$ & $-3.17(0.45) \mathrm{a}$ & $-2.96(0.44) \mathrm{a}$ & $-5.06(0.61) b$ & $-2.96(0.36) \mathrm{a}$ & $-3.52(0.39) \mathrm{a}$ & $-3.17(0.37) \mathrm{a}$ & $-4.98(0.34) b$ & $-3.59(0.36) \mathrm{a}$ \\
\hline $\mathrm{SOC}\left(\mathrm{g} \mathrm{kg}^{-1}\right)$ & $8.30(3.58) \mathrm{a}$ & $1.01(0.16) \mathrm{b}$ & $4.39(1.20) \mathrm{b}$ & $1.12(0.39) \mathrm{b}$ & $3.86(1.37) \mathrm{b}$ & $1.07(0.51) \mathrm{b}$ & $3.65(0.89) \mathrm{b}$ & $1.36(0.73) \mathrm{b}$ \\
\hline SIC $\left(\mathrm{g} \mathrm{kg}^{-1}\right)$ & $11.9(1.1) \mathrm{a}$ & $11.0(0.6) \mathrm{a}$ & $17.8(2.2) \mathrm{b}$ & $10.8(0.7) \mathrm{a}$ & $10.0(1.2) \mathrm{a}$ & $10.9(1.6) \mathrm{a}$ & $17.6(1.5) \mathrm{b}$ & 11.7 (1.9) a \\
\hline
\end{tabular}

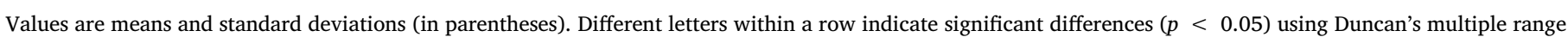

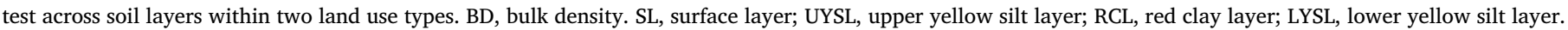

\section{Results}

\subsection{Carbon variations in soil layers of typical soil profiles}

Soil $\mathrm{pH}$ was high and showed no significant difference between wetland and farmland at the different soil depths (Table 1). Soil salinity was higher in wetland than in farmland, especially in the SL. Bulk density was lower in the RCL than in the other parts of the soil profile. The RCL samples were dominated by clayey silt while other soil layers consisted mainly of silt and sandy silt. $\chi_{\text {ARM }} /$ SIRM values in the RCL were almost three times higher than in the other layers. SL, UYSL and LYSL showed similar $\chi_{\text {ARM }} /$ SIRM values indicating a similar provenance (Li et al., 2018). The RCL showed unique soil properties in both wetland and farmland soils.

The $\delta^{13} \mathrm{C}_{\mathrm{SOC}}$ values showed an overall depletion of ${ }^{13} \mathrm{C}$ in SOC in the topsoil but enrichment in the subsoil in both wetland and farmland. The $\delta^{13} \mathrm{C}_{\text {SIC }}$ values, ranging from $-73 \%$ to $-2.26 \%$, showed sharp decrease in the RCL in both wetland and farmland.

SOC content decreased by $54 \%$ in the topsoil after converting wetland to farmland. Subsoil SOC contents in the RCL were much higher than in the UYSL and LYSL in both land use types and were comparable to the SL in farmland. SIC contents were about 1.4 to 11 times higher than that of SOC over all the soil layers in soil profiles. In contrast to SOC, the highest SIC content was found in the RCL from the subsoil while SIC content among other soil layers were very similar under different land use types.

The average SOC stocks were $1.94 \pm 1.12 \mathrm{~kg} \mathrm{C} \mathrm{m}^{-2}$ (wetland 0-30 cm), $2.05 \pm 1.28 \mathrm{~kg} \mathrm{C} \mathrm{m}{ }^{-2}$ (wetland $30-100 \mathrm{~cm}$ ), $1.29 \pm 0.43 \mathrm{~kg} \mathrm{C} \mathrm{m}^{-2}$ (farmland $0-30 \mathrm{~cm}$ ) and $1.42 \pm 0.73 \mathrm{~kg} \mathrm{C} \mathrm{m}^{-2}$ (farmland $30-100 \mathrm{~cm}$ ), respectively, whereas average SIC stocks were $4.73 \pm 0.64 \mathrm{~kg} \mathrm{C} \mathrm{m}^{-2}$ (wetland $0-30 \mathrm{~cm}$ ), $13.1 \pm 1.9 \mathrm{~kg} \mathrm{C} \mathrm{m}^{-2}$ (wetland 30-100 cm), $4.39 \pm 0.91 \mathrm{~kg} \mathrm{C} \mathrm{m}^{-2}$ (farmland $0-30 \mathrm{~cm}$ ) and $11.9 \pm 2.1 \mathrm{~kg} \mathrm{C} \mathrm{m}^{-2}$ (farmland $30-100 \mathrm{~cm}$ ). The SOC stock in the subsoil was comparable to that in the topsoil while the SIC stock in the subsoil was much higher.

\subsection{Carbon variations in high-resolution soil profiles}

Typical high-resolution soil profiles were used to show soil property variations and to calculate carbon accumulation rates. The $\delta^{13} \mathrm{C}_{\mathrm{SIC}}$ values, $\chi_{\text {ARM }}$ SIRM values, and $C$ stocks in high-resolution soil profiles from wetland and farmland often varied widely (Fig. 2). The RCL in the profiles contained markedly low values of $\delta^{13} \mathrm{C}_{\text {SIC }}$ and high values of $\chi_{\text {ARM }} /$ SIRM and high stocks of SOC and SIC. The average SIC stock in the RCL was about 1.6 times higher than in the YSL. Although the SOC stock was maximum in the top $15 \mathrm{~cm}$ of wetland, it was much higher in the RCL than in the YSL (Fig. 2a). It is also notable that the C-enriched
RCL all occurred below $80 \mathrm{~cm}$ in the farmland and the $\mathrm{C}$ stocks varied slightly in the YSL (Fig. 2b).

The accumulation rates (AR) of SOC and SIC were always correlated with the mass accumulation rates (MAR) (Fig. 2), indicating that changes in the sedimentary environment such as episodic flood discharge from the Yellow River and tidal current patterns likely altered the delivery rates of mineral-associated carbon. The average AR of SOC and SIC in the RCL from the two profiles was 52.7 \pm 26.1 and $197 \pm 95 \mathrm{~g} \mathrm{C} \mathrm{m}^{-2} \mathrm{yr}^{-1}$, respectively. The average AR of SOC and SIC in the YSL from the two profiles was $27.0 \pm 17.6$ and $144 \pm 84 \mathrm{~g} \mathrm{C}$ $\mathrm{m}^{-2} \mathrm{yr}^{-1}$, respectively. The average AR of SOC in the RCL was significantly higher than that in the YSL. The average AR of SIC (179 $\pm 105 \mathrm{~g} \mathrm{C} \mathrm{m}^{-2} \mathrm{yr}^{-1}$ ) was about 3.5 times higher than the average AR of SOC $\left(51.9 \pm 37.5 \mathrm{~g} \mathrm{C} \mathrm{m}^{-2} \mathrm{yr}^{-1}\right)$ throughout the two soil profiles.

In the Arabian Gulf (a hotspot of carbonate production) the average $\mathrm{AR}$ of SIC in blue carbon ecosystem soils is about $148 \pm 63 \mathrm{~g} \mathrm{C} \mathrm{m}^{-2}$ $\mathrm{yr}^{-1}$ over the last decades/century (Saderne et al., 2018). Although the SIC content $\left(72.0 \pm 7.4 \mathrm{~g} \mathrm{~kg}^{-1}\right)$ in coastal soils of the Arabian Gulf is about 5.5 times higher than in the YRD soil (Saderne et al., 2018), SIC AR in soils of the YRD is comparable to that in the Arabian Gulf. The high SIC AR in the YRD can be attributed to its high MAR $\left(1.31 \pm 0.68 \mathrm{~cm} \mathrm{yr}^{-1}\right)$ which is approximately one order of magnitude higher than in the Arabian Gulf.

\section{Discussion}

\subsection{Importance of subsoil for carbon storage}

The vegetation in the wetland and farmland studied in the YRD is dominated by C3 plants (e.g. suaeda, reed and cotton) (Li et al., 2016). The more negative $\delta^{13} \mathrm{C}_{\mathrm{SOC}}$ values in the topsoil imply that the organic carbon is mainly sourced from the input of the fresh plant litters. The more positive $\delta^{13} \mathrm{C}_{\mathrm{SOC}}$ values in the subsoil can be attributed to the contribution of substrate (e.g., loess) inherent refractory carbon, which is highly processed with ${ }^{13} \mathrm{C}$ enriched compounds (Rumpel and KögelKnabner, 2011). The $\delta^{13} \mathrm{C}_{\text {SIC }}$ values are similar in the topsoil in both wetland and farmland, indicating that there is little variation in carbonate composition in the topsoil in association with cropping. However, the sharp decrease in $\delta^{13} \mathrm{C}_{\mathrm{SIC}}$ values in the RCL in both wetland and farmland suggests that there may be secondary carbonates in the subsoil (see Sections 4.3 and 4.4).

The carbon content, stock and accumulation rate results are consistent with previous findings indicating that subsoil $\mathrm{C}$ may be even more important than topsoil C for C sequestration (Rumpel and KögelKnabner, 2011; Wang et al., 2015; Guo et al., 2016; Shi et al., 2017). However, these studies may have overlooked the importance of 

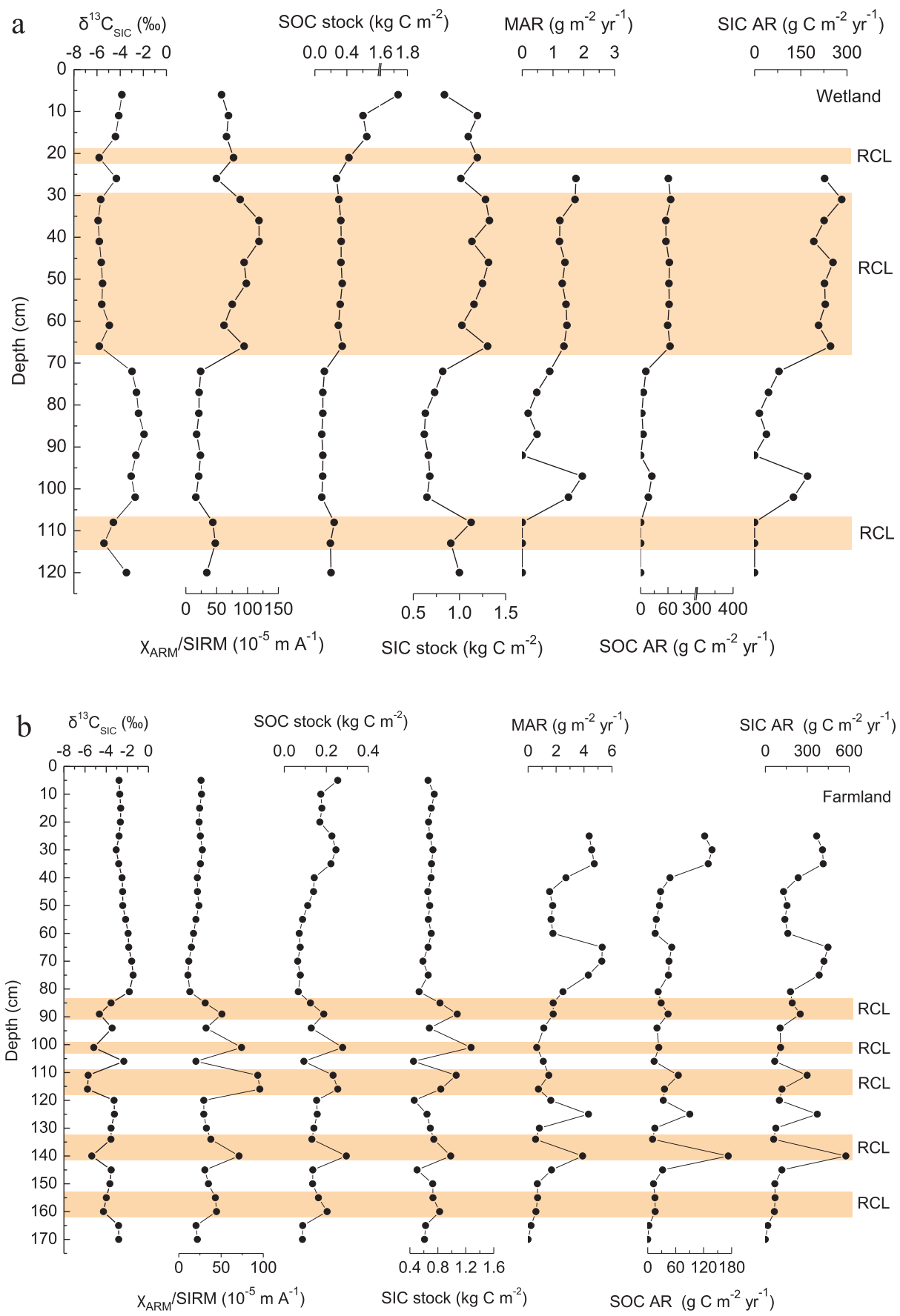

Fig. 2. High-resolution soil profiles of $\delta^{13} \mathrm{C}_{\text {SIC }}$ and $\chi_{\text {ARM }} /$ SIRM values, stocks and mass accumulation rates (MAR) of SOC and SIC from (a) wetland and (b) farmland in the Yellow River Delta. RCL, red clay layer.

characteristic soil layers. The RCL clay-enriched layer that is widely distributed in the YRD but may also occur frequently on alluvial plains receiving loess deposits or periodic sediments (Muhs, 2007; Bockheim and Hartemink, 2013). The stability of SOC in the subsoil is soil-type specific and dependent on pedological processes rather than on its molecular structure alone (Schmidt et al., 2011; Spielvogel et al., 2008). The increase in SOC stock in the subsoil may lead to an increase in SIC stocks through neoformation of secondary carbonate (Guo et al., 2016; Wang et al., 2018). The subsoil with unique soil properties may facilitate the sequestration of SOC and SIC, which links the long-term geological $\mathrm{C}$ cycle with the short-term biological $\mathrm{C}$ cycle.

It is well-known that more organic matter and secondary carbonate are associated with finer mineral particles in soils and sediments
(Bianchi, 2011). Our results suggest that in the new-born coastal wetland under short-term reclamation, the difference of $\mathrm{C}$ stocks between wetland and farmland mainly occurs in the top $20-30 \mathrm{~cm}$, whereas $\mathrm{C}$ stocks in the subsoil are determined principally by the efficiency of the accumulation of C-rich fine particles. Moreover, belowground C production from root decomposition and respiration may be also an important mechanism in SOC and secondary carbonate accumulation in subsoil, especially in wetland dominated by deeply rooted plants (e.g., reed) (Bughio et al., 2016; Miyajima et al., 2015).

\subsection{Stabilization of carbonate in the RCL}

The CLP with its remarkable loess-palaeosol-red clay sequence 

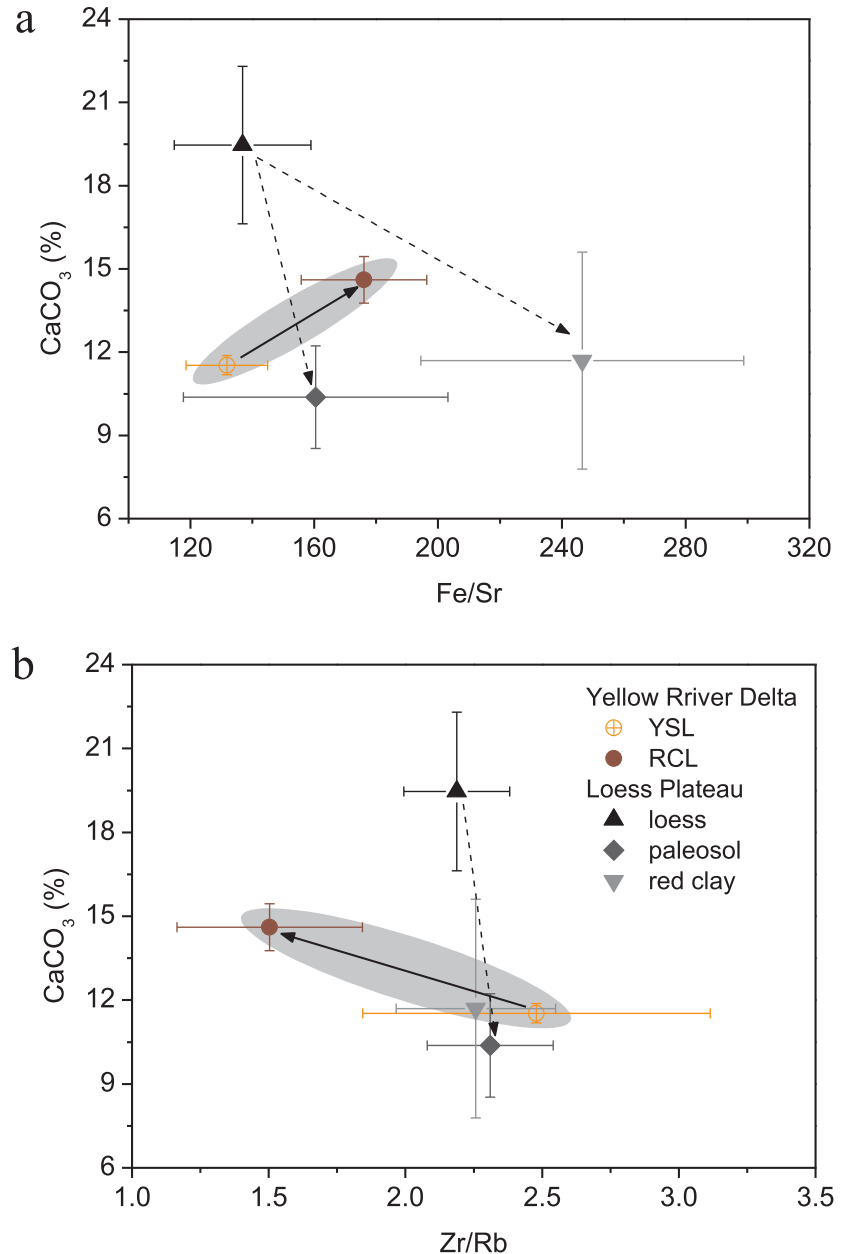

Fig. 3. Comparison of $\mathrm{CaCO}_{3}$ contents versus (a) $\mathrm{Fe} / \mathrm{Sr}$ ratios and (b) $\mathrm{Zr} / \mathrm{Rb}$ ratios in soil layers between the Yellow River Delta (YSL-RCL sequence) and Chinese Loess Plateau (loess-paleosol-red clay sequence). YSL, yellow silt layer; RCL, red clay layer. $\mathrm{CaCO}_{3}, \mathrm{Fe}, \mathrm{Sr}, \mathrm{Zr}$ and $\mathrm{Rb}$ data from the Chinese Loess Plateau are compiled from Ding et al. (2001).

contributes nearly $90 \%$ of the sediment of the Yellow River (Wang et al., 2015) and acts as a most important source region of materials deposited in the YRD. The YSL-RCL sequence is formed mainly by sedimentary sorting from the Yellow River sediment and highly-weathered fine sediments (such as paleosols) from the basin may be the main source materials comprising the RCL (Li et al., 2019). Thus, comparison between the YSL-RCL sequence in the YRD and the loess-palaeosol-red clay sequence in the CLP can reflect variation in carbon storage through transportation and deposition. Eight loess-palaeosol-red clay sections along a north-south transect in the CLP (Ding et al., 2001) were selected for comparison with the YSL-RCL sequence in the YRD (Fig. 3). The Fe/ $\mathrm{Sr}$ ratio was selected as a proxy for weathering intensity because $\mathrm{Fe}$ is more stable than $\mathrm{Sr}$ in the weakly-weathered loess successions of the CLP (Liang et al., 2012). A higher Fe/Sr ratio indicates higher weathering intensity. The $\mathrm{Zr} / \mathrm{Rb}$ ratio is used to reflect grain size variation because loess deposit $\mathrm{Zr}$ is enriched in the coarser fraction whereas $\mathrm{Rb}$ tends to be enriched in the finer fraction (Chen et al., 2006). The $\mathrm{Zr} / \mathrm{Rb}$ ratio increases substantially from the finest to the coarsest fraction.

In the CLP the loess layers have higher carbonate contents and lower weathering intensity while the paleosols as pedogenic products have lower carbonate contents and higher weathering intensity (Fig. 3a). The red clay has moderate carbonate contents and strong weathering intensity. Grain sizes in the loess-paleosol-red clay sequence exhibit little variation (Fig. 3b). In the YRD, however, carbonate contents show a clear increasing trend relative to $\mathrm{Fe} / \mathrm{Sr}$ ratios in the
YSL-RCL sequence. It is notable that although showing a similar weathering trend, the YSL-RCL sequence in the YRD displays distinct differences in carbonate contents compared to the loess-paleosol-red clay sequence in the CLP. In addition, $\mathrm{Zr} / \mathrm{Rb}$ ratios show a decreasing trend in the YSL-RCL sequence and they are lowest of all the layers in the RCL (Fig. 3b). The results indicate that fine-grained particles with higher weathering intensity in the Yellow River transported materials can capture carbonate. That is, particle size and secondary products are both important factors altering the carbon pool from source to sink.

\subsection{Identification of secondary carbonate in the $R C L$}

Stable isotope techniques have been used successfully to estimate the extent of secondary carbonate formation due to distinct differences between the isotopic values of secondary and primary carbonates (Landi et al., 2003; Washbourne et al., 2012; Zamanian et al., 2016). In general, the $\delta^{13} \mathrm{C}_{\text {SIC }}$ value in primary carbonate is close to $0 \%$ but the values in secondary carbonates are about $-12 \%$ under pure C3 and $+2 \%$ under pure C4 vegetation (Cerling, 1984; Zamanian et al., 2016). The negative correlation between SIC and $\delta^{13} C_{\text {SIC }}$ throughout the dataset and more negative $\delta^{13} \mathrm{C}_{\text {SIC }}$ values in the RCL (Fig. 4a) indicate a larger contribution of secondary carbonates under $\mathrm{C} 3$ vegetation in the RCL.

Magnetic parameters are extremely useful in investigating pedogenesis and paleoclimatic change (Roberts, 2015). $\chi_{\text {ARM }} /$ SIRM is a magnetic parameter that is sensitive to pedogensis, producing large amounts of fine stable single domain (SSD) and small pseudo-single domain (PSD) magnetic grains having high $\chi_{\text {ARM }} /$ SIRM values (Liu et al., 2007; Li et al., 2018). Recently, Nie et al. (2014) also reported that $\chi_{\text {ARM }} /$ SIRM values was highly sensitive to precipitation and temperature variation, with higher (lower) $\chi_{\text {ARM }} /$ SIRM values corresponding to higher (lower) precipitation and temperature. Our previous studies found that the RCL with higher contents of secondary minerals was separated from a mixed source from the basin and was likely derived from highly weathered sediments that had experienced a warmer climate (Li et al., 2018, 2019). The RCL with highest SIC contents had highest $\chi_{\text {ARM }} /$ SIRM values (Table 1 ). Throughout the dataset the $\chi_{\text {ARM }} /$ SIRM values were negatively correlated with the $\delta^{13} \mathrm{C}_{\text {SIC }}$ values and positively with the SIC contents (Fig. $4 \mathrm{~b}$ and c). This implies that carbonate formed under stronger pedogenesis during warmer paleoclimate may be an important source of SIC in the RCL. However, carbonate dissolution and leaching are also stronger when climatic conditions are warmer and wetter (Ding et al., 2001). The enhanced carbonate in the RCL may be attributed to the adsorption of dissolved secondary carbonate (e.g., carbonate nodules, rhizoliths, etc.) or the uptake of atmospheric $\mathrm{CO}_{2}$ (see Section 4.4).

It is notable that strongly and moderately positive correlations between SIC and SOC in the YSL-RCL sequence and SL were observed, respectively (Fig. 4d). The dissolution and precipitation of carbonate (taking $\mathrm{CaCO}_{3}$ as an example) involves two main reactions (Wang et al., 2015):

$\mathrm{CO}_{2}+\mathrm{H}_{2} \mathrm{O} \rightleftharpoons \mathrm{HCO}_{3}{ }^{-}+\mathrm{H}^{+}$

$\mathrm{Ca}^{2+}+2 \mathrm{HCO}_{3}{ }^{-} \rightleftharpoons \mathrm{CaCO}_{3}+\mathrm{H}_{2} \mathrm{O}+\mathrm{CO}_{2}$

In general, higher SOC can cause higher $\mathrm{CO}_{2}$ concentrations in soils and lead to production of both $\mathrm{HCO}_{3}{ }^{-}$and $\mathrm{H}^{+}$. Because the soil has a $\mathrm{pH}>8$ with no $\mathrm{Ca}^{2+}$ and/or $\mathrm{Mg}^{2+}$ limitation in the YRD (Table 1), the large buffering capacity will let the remaining $\mathrm{HCO}_{3}{ }^{-}$drive reaction (4) to the right and produce SIC. The positive correlations imply that an enhancement of SOC may lead to an increase in SIC through the neoformation of secondary carbonate (Guo et al., 2016; Wang et al., 2018), especially in the subsoil YSL-RCL sequence with relatively low SOC content. 

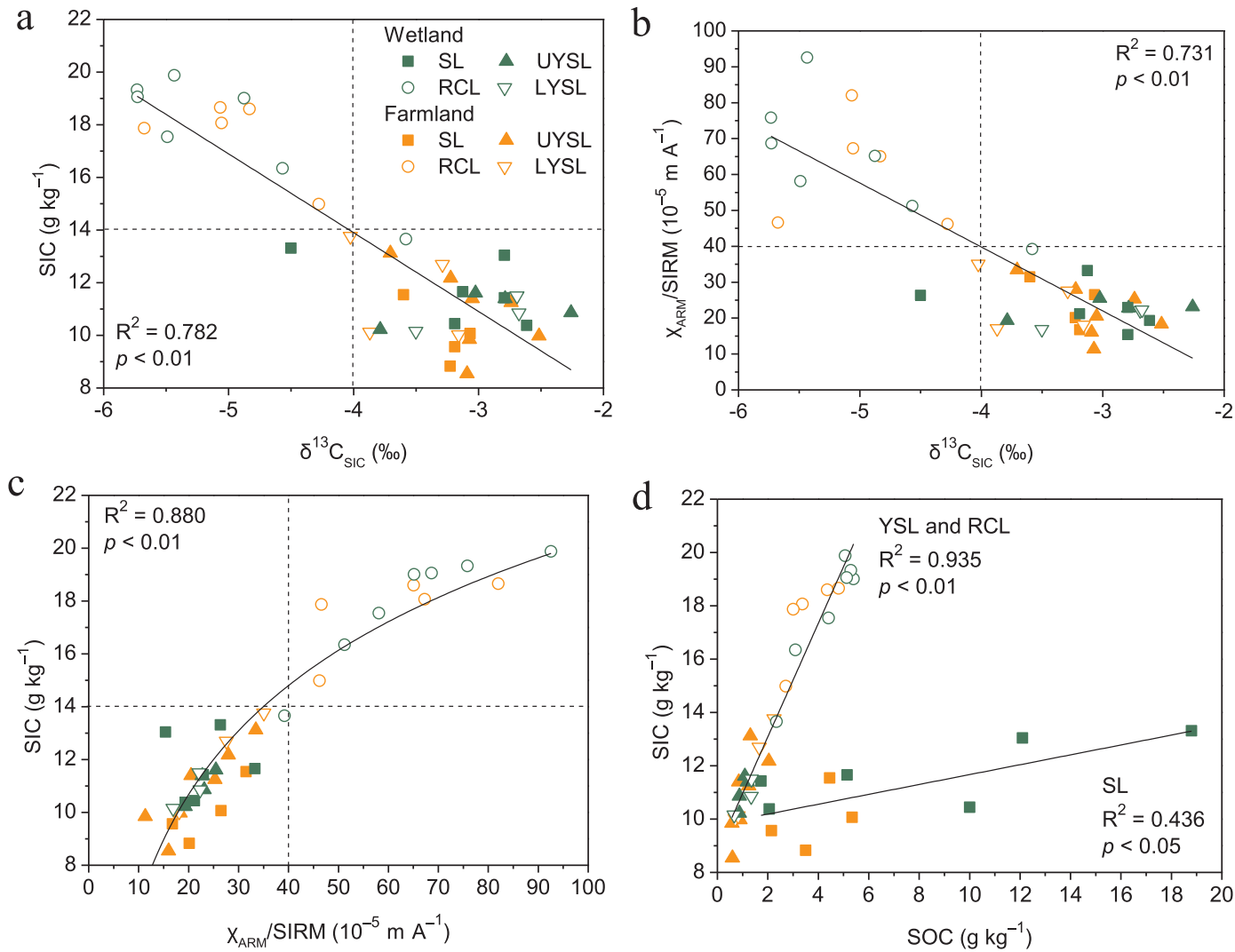

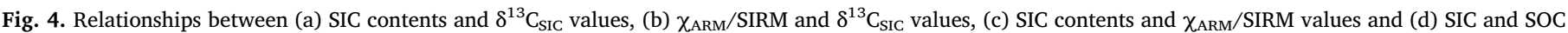

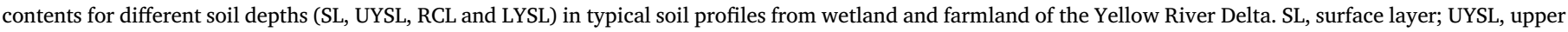
yellow silt layer; RCL, red clay layer; LYSL, lower yellow silt layer.

\subsection{Possible sources of secondary carbonate in the RCL}

Based on the above discussion the carbonate accumulation in the
RCL may be attributed to the contribution of secondary carbonate (Fig. 5). In the CLP, the source region of the YRD soil, the $\delta^{13} \mathrm{C}_{\text {SIC }}$ of paleosols formed during the warm, moist interglacials is negative,

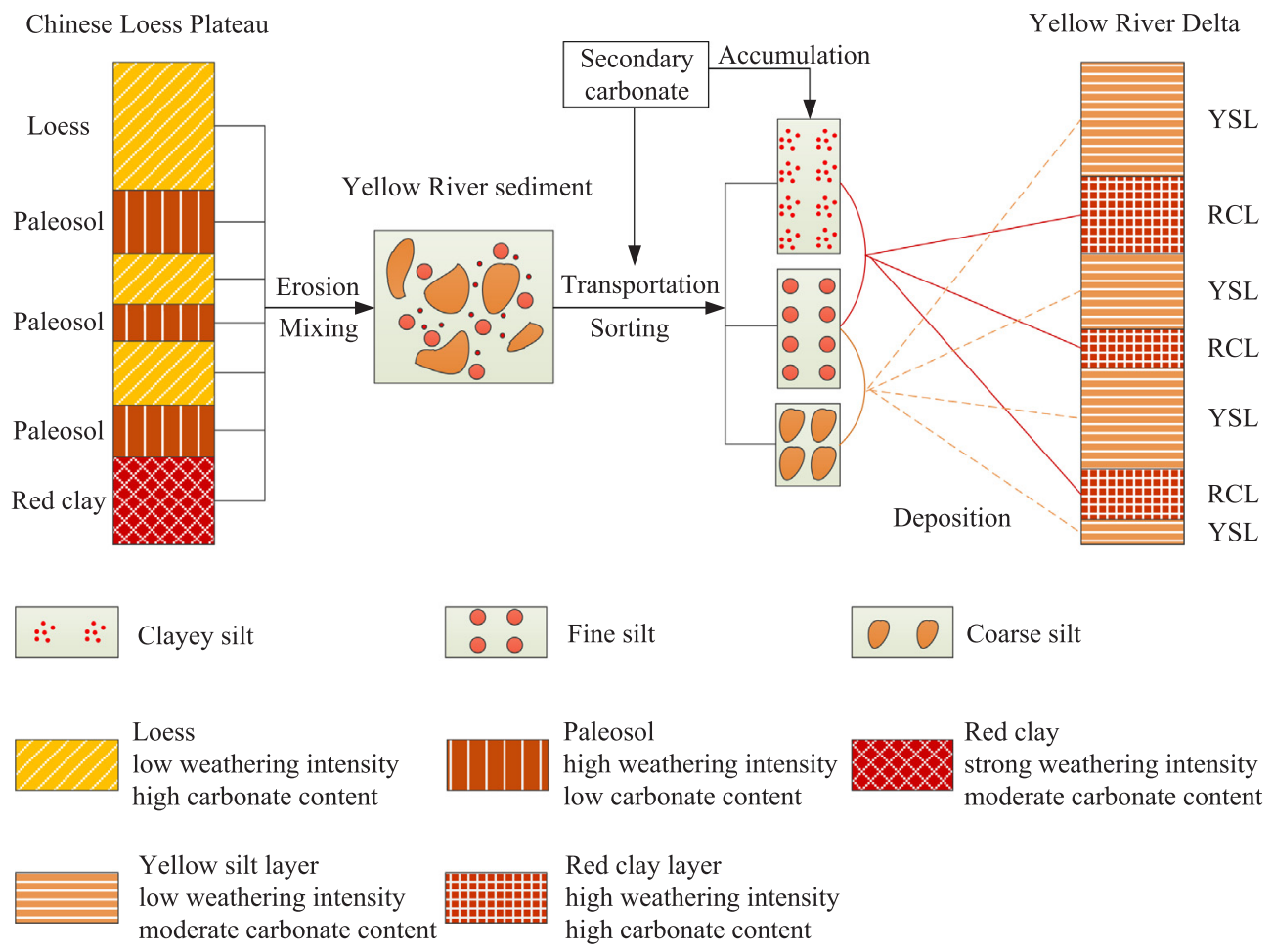

Fig. 5. Conceptual framework of carbonate accumulation during transportation and deposition of loess-derived sediments in the Yellow River Delta. 
becoming more positive in loess accumulation under cold, dry glacial conditions (Rao et al., 2006). The $\delta^{13} \mathrm{C}_{\text {SIC }}$ results of the YRD are similar to those of the CLP, both showing that the most developed soil layers have the most negative $\delta^{13} \mathrm{C}_{\text {SIC }}$ values. However, the difference is that the soil layers with a stronger degree of weathering contain more carbonate in the YRD while the opposite holds in the CLP. This indicates that the weathered fine particles transported by the Yellow River can capture secondary carbonate.

Wang et al. (2016) found that $73.4 \pm 3.0 \%$ of DIC (1060-1370 yr old) in the Yellow River was from the uptake of atmospheric $\mathrm{CO}_{2}$ during silicate weathering. However, Pang et al. (2018) reported that riverbed sediments from the trunk-river channel, floodplain, and major tributaries in the Yellow River basin had not experienced intense chemical weathering due to rapid transport and dry climatic conditions. This suggests that adsorption and precipitation of atmospheric derived DIC may be an important source of carbonate accumulation in the RCL. The accumulation of carbonate in water and suspended particles and in deltaic sediment deposits in the Yellow River delta-estuary is likely associated with silicate weathering during riverine transport, emphasizing the potential importance of this latter process to carbon sequestration.

\section{Conclusions}

In the YRD the difference in C stocks between wetland and farmland occurs mainly in the top $20-30 \mathrm{~cm}$ whereas $\mathrm{C}$ stocks in the subsoil are determined principally by the efficiency of the accumulation of C-rich fine particles. The average AR of SOC $(52.7 \pm 26.1)$ and SIC $\left(197 \pm 95 \mathrm{~g} \mathrm{C} \mathrm{m}^{-2} \mathrm{yr}^{-1}\right)$ in the RCL is significantly higher than in the YSL. The $\delta^{13} \mathrm{C}_{\text {SIC }}$ and $\chi_{\text {ARM }} /$ SIRM results indicate that the RCL with a stronger degree of weathering contain more secondary carbonate which may have been formed partly under stronger pedogenesis during the warmer paleoclimate in the source region. The YSL-RCL sequence in the YRD shows distinct differences in carbonate and $\mathrm{Zr} / \mathrm{Rb}$ ratio compared to the loess-paleosol-red clay sequence in the Chinese Loess Plateau, indicating significant changes in the dissolved and suspended loads and emphasizing the potential importance of riverine transport in the basin for carbon sequestration.

\section{Declaration of Competing Interest}

The authors declared that there is no conflict of interest.

\section{Acknowledgements}

This work was funded by the National Natural Science Foundation of China (41701263, 41807418 and 41501522), Yantai Science and Technology Project (2017ZH091), the National Key Research and Development Program of China (2018YFC1801001) and the Sino-German Joint Project on Marine and Polar Cooperation (FINGBOYEL). We thank Dr Peter Christie, Nanjing Institute of Soil Science, CAS, for his careful proofreading and revision. We thank two anonymous reviewers for their important and helpful comments.

\section{Appendix A. Supplementary material}

Supplementary data to this article can be found online at https:// doi.org/10.1016/j.catena.2019.104391.

\section{References}

Batjes, N.H., 1996. Total carbon and nitrogen in the soils of the world. Eur. J. Soil Sci. 47, 151-163.

Bauer, J.E., Cai, W.J., Raymond, P.A., Bianchi, T.S., Hopkinson, C.S., Regnier, P.A., 2013. The changing carbon cycle of the coastal ocean. Nature 504, 61-70.

Bianchi, T.S., 2011. The role of terrestrially derived organic carbon in the coastal ocean: a changing paradigm and the priming effect. Proc. Natl. Acad. Sci. USA 108,
19473-19481.

Bianchi, T.S., Allison, M.A., 2009. Large-river deltafront estuaries as natural "recorders" of global environmental change. Proc. Natl. Acad. Sci. USA 106, 8085-8092.

Bockheim, J.G., Hartemink, A.E., 2013. Distribution and classification of soils with clay enriched horizons in the USA. Geoderma 209, 153-160.

Bouchez, J., Gaillardet, J., Lupker, M., Louvat, P., France-Lanord, C., Maurice, L., Armijos, E., Moquet, J.S., 2012. Floodplains of large rivers: weathering reactors or simple silos? Chem. Geol. 332, 166-184.

Bughio, M.A., Wang, P.L., Meng, F.Q., Qing, C., Kuzyakov, Y., Wang, X.J., Junejo, S.A., 2016. Neoformation of pedogenic carbonates by irrigation and fertilization and their contribution to carbon sequestration in soil. Geoderma 262, 12-19.

Cerling, T.E., 1984. The stable isotopic composition of modern soil carbonate and its relationship to climate. Earth Planet. Sci. Lett. 71, 229-240.

Chen, J., Chen, Y., Liu, L.W., Ji, J.F., Balsam, W., Sun, Y.B., Lu, H.Y., 2006. Zr/Rb ratio in the Chinese loess sequences and its implication for changes in the East Asian winter monsoon strength. Geochim. Cosmochim. Acta 70, 1471-1482.

Cole, J.J., Prairie, Y.T., Caraco, N.F., McDowell, W.H., Tranvik, L.J., Striegl, R.G., Duarte, C.M., Kortelainen, P., Downing, J.A., Middelburg, J.J., Melack, J., 2007. Plumbing the global carbon cycle: Integrating inland waters into the terrestrial carbon budget. Ecosystems 10, 171-184.

Ding, Z.L., Sun, J.M., Yang, S.L., Liu, T.S., 2001. Geochemistry of the Pliocene red clay formation in the Chinese Loess Plateau and implications for its origin, source provenance and paleoclimate change. Geochim. Cosmochim. Acta 65, 901-913.

Eswaran, H., Van den Berg, E., Reich, P., Kimble, J., 1995. Global soil carbon resources. In: Lal, R., Kimble, J., Levine, E., Stewart, B.A. (Eds.), Soils and Global Change Advances in Soil Sci. CRC Press, Boca Raton, FL, pp. 27-44.

Eswaran, H., Reich, P.F., Kimble, J.M., Beinroth, F.H., Padmanabhan, E., Moncharoen, P., 2000. Global carbon stocks. In: Lal, R., Kimble, J.M., Eswaran, H., Stewart, B.A. (Eds.), Global Climate Change and Pedogenic Carbonates. CRC Press, Boca Raton, FL, pp. 15-25.

Frings, P.J., Clymans, W., Fontorbe, G., Gray, W., Chakrapani, G.J., Conley, D.J., De La Rocha, C., 2015. Silicate weathering in the Ganges alluvial plain. Earth Planet. Sci. Lett. 427, 136-148.

Gunal, H., Ransom, M.D., 2006. Clay illuviation and calcium carbonate accumulation along a precipitation gradient in Kansas. Catena 68, 59-69.

Guo, Y., Wang, X.J., Li, X.L., Wang, J.P., Xu, M.G., Li, D.W., 2016. Dynamics of soil organic and inorganic carbon in the cropland of upper Yellow River Delta, China. Sci. Rep. 6, 36105.

Han, G.X., Xing, Q.H., Yu, J.B., Luo, Y.Q., Li, D.J., Yang, L.Q., Wang, G.M., Mao, P.L., Xie, B.H., Mikle, N., 2014. Agricultural reclamation effects on ecosystem $\mathrm{CO}_{2}$ exchange of a coastal wetland in the Yellow River Delta. Agr. Ecosyst. Environ. 196, 187-198.

Khormali, F., Ghergherechi, S., Kehl, M., Ayoubi, S., 2012. Soil formation in loess-derived soils along a subhumid to humid climate gradient, Northeastern Iran. Geoderma 179-180, 113-122.

Kristensen, E., Bouillon, S., Dittmar, T., Marchand, C., 2008. Organic carbon dynamics in mangrove ecosystems: a review. Aquat. Bot. 89, 201-219.

Lal, R., 2004. Soil carbon sequestration impacts on global climate change and food security. Science 304, 1623-1627.

Lal, R., Kimble, J.M., 2000. Pedogenic carbonates and the global carbon cycle. In: Kimble, J.M., Eswaran, H., Stewart, B.A. (Eds.), Global Climate Change and Pedogenic Carbonates. CRC Press, Boca Rton, FL, pp. 1-14.

Landi, A., Mermut, A.R., Anderson, D.W., 2003. Origin and rate of pedogenic carbonate accumulation in Saskatchewan soils, Canada. Geoderma 117, 143-156.

Li, Y., Zhang, H.B., Fu, C.C., Tu, C., Luo, Y.M., Christie, P., 2019. A red clay layer in soils of the Yellow River Delta: Occurrence, properties and implications for elemental budgets and biogeochemical cycles. Catena 172, 469-479.

Li, Y., Zhang, H.B., Tu, C., Fu, C.C., Xue, Y., Luo, Y.M., 2016. Sources and fate of organic carbon and nitrogen from land to ocean: Identified by coupling stable isotopes with C/N ratio. Estuar. Coast. Shelf Sci. 181, 114-122.

Li, Y., Zhang, H.B., Tu, C., Luo, Y.M., 2018. Magnetic characterization of distinct soil layers and its implications for environmental changes in the coastal soils from the Yellow River Delta. Catena 162, 245-254.

Liang, L.J., Sun, Y.B., Yao, Z.Q., Liu, Y.G., Wu, F., 2012. Evaluation of high-resolution elemental analyses of Chinese loess deposits measured by X-ray fluorescence core scanner. Catena 92, 75-82.

Liu, Q.S., Deng, C.L., Torrent, J., Zhu, R.X., 2007. Review of recent developments in mineral magnetism of the Chinese loess. Quat. Sci. Rev. 26, 368-385.

Liu, Z., Dreybrodt, W., Wang, H., 2010. A new direction in effective accounting for the atmospheric $\mathrm{CO} 2$ budget: considering the combined action of carbonate dissolution, the global water cycle and photosynthetic uptake of DIC by aquatic organisms. EarthSci. Rev. 99, 162-172.

MacReadie, P.I., Hughes, A.R., Kimbro, D.L., 2013. Loss of "blue carbon" from coastal salt marshes following habitat disturbance. PLoS One 8, e69244-e69248.

Mazarrasa, I., Marbà, N., Lovelock, C.E., Serrano, O., Lavery, P.S., Fourqurean, J.W., Kennedy, H., Mateo, M.A., Krause-Jensen, D., Steven, A.D., Duarte, C.M., 2015. Seagrass meadows as a globally significant carbonate reservoir. Biogeosciences 12 , 4993-5003.

McLeod, E., Chmura, G.L., Bouillon, S., Salm, R., Björk, M., Duarte, C.M., Lovelock, C.E., Schlesinger, W.H., Silliman, B.R., 2011. A blueprint for blue carbon: toward an improved understanding of the role of vegetated coastal habitats in sequestering $\mathrm{CO}_{2}$. Front. Ecol. Environ. 9, 552-560.

Mi, N.A., Wang, S., Liu, J., Yu, G., Zhang, W., Jobbagy, E., 2008. Soil inorganic carbon storage pattern in China. Global Change Biol. 14, 2380-2387.

Milliman, J.D., Syvitski, J.P.M., 1992. Geomorphic/tectonic control of sediment discharge to the ocean: the importance of small mountainous rivers. J. Geol. 100, 525-544. 
Miyajima, T., Hori, M., Hamaguchi, M., Shimabukuro, H., Adachi, H., Yamano, H., Nakaoka, M., 2015. Geographic variability in organic carbon stock and accumulation rate in sediments of East and Southeast Asian seagrass meadows. Global Biogeochem. Cy. 29, 397-415.

Monger, H.C., Kraimer, R.A., Khresat, S., Cole, D.R., Wang, X.J., Wang, J.P., 2015 Sequestration of inorganic carbon in soil and groundwater. Geology 43, 375-378.

Muhs, D.R., 2007. Loess deposits, origins and properties. In: Encyclopedia of Quaternary Sciences. Elsevier, pp. 1405-1418.

Nie, J.S., Stevens, T., Song, Y.G., King, J.W., Zhang, R., Ji, S.C., Gong, L.S., Cares, D., 2014. Pacific freshening drives Pliocene cooling and Asian monsoon intensification. Sci. Rep. 4, 5474.

Nieder, R., Benbi, D.K., 2008. Carbon and Nitrogen in the Terrestrial Environment. Springer.

Pang, H.L., Pan, B.T., Garzanti, E., Gao, H.S., Zhao, X., Chen, D.B., 2018. Mineralogy and geochemistry of modern Yellow River sediments: implications for weathering and provenance. Chem. Geol. 488, 76-86.

Pang, J.Z., Si, S.H., 1979. The estuary changes of Huanghe River I. Changes in modern time. Oceanol. Lomnol. Sin. 10, 136-141 (in Chinese with English abstract).

Rao, Z.G., Zhu, Z.Y., Chen, F.H., Zhang, J.W., 2006. Does $\delta^{13} C_{\text {carb }}$ of the Chinese loess indicate past $\mathrm{C}_{3} / \mathrm{C}_{4}$ abundance? A review of research on stable carbon isotopes of the Chinese loess. Quat. Sci. Rev. 25, 2251-2257.

Roberts, A.P., 2015. Magnetic mineral diagenesis. Earth Sci. Rev. 151, 1-47.

Rumpel, C., Kögel-Knabner, I., 2011. Deep soil organic matter: a key but poorly understood component of terrestrial C cycle. Plant Soil 338, 143-158.

Saderne, V., Cusack, M., Almahasheer, H., Serrano, O., Masqué, P., Arias-Ortiz, A., Krishnakumar, P.K., Rabaoui, L., Qurban, M.A., Duarte, C.M., 2018. Accumulation of carbonates contributes to coastal vegetated ecosystems keeping pace with sea level rise in an arid region (Arabian Peninsula). J. Geophys. Res. Biogeo. 123, 1498-1510.

Saito, Y., Wei, H.L., Zhou, Y.Q., Nishimura, A., Sato, Y., Yokota, S., 2000. Delta progradation and chenier formation in the Huanghe (Yellow River) delta, China. J. Asian Earth Sci. 18, 489-497.

Sanchez-Cabeza, J.A., Ruiz-Fernández, A.C., 2012. ${ }^{210} \mathrm{~Pb}$ sediment radiochronology: an integrated formulation and classification of dating models. Geochim. Cosmochim.
Acta 82, 183-200.

Scharpenseel, H.W., Mtimet, A., Freytag, J., Lal, R., Kimble, J.M., Eswaran, H., Stewart, B.A., 2000. Soil inorganic carbon and global change. In: Kimble, J.M., Eswaran, H., Stewart, B.A. (Eds.), Global Climate Change and Pedogenic Carbonates. CRC Press, Boca Rton, FL, pp. 27-42.

Schmidt, M.W.I., Torn, M.S., Abiven, S., Dittmar, T., Guggenberger, G., Janssens, I.A. Kleber, M., Kögel-Knabner, I., Lehmann, J., Manning, D.A.C., Nannipieri, P., Rasse, D.P., Weiner, S., Trumbore, S.E., 2011. Persistence of soil organic matter as an ecosystem property. Nature 478, 49-56.

Shi, H.J., Wang, X.J., Zhao, Y.J., Xu, M.G., Li, D.W., Guo, Y., 2017. Relationship between soil inorganic carbon and organic carbon in the wheat-maize cropland of the North China Plain. Plant Soil 418, 423-436.

Spielvogel, S., Prietzel, J., Kögel-Knabner, I., 2008. Soil organic matter stabilisation in acidic forest soils is preferential and soil type-specific. Eur. J. Soil Sci. 59, 674-692.

Wang, X.C., Luo, C.L., Ge, T.T., Xu, C.L., Xue, Y.J., 2016. Controls on the sources and cycling of dissolved inorganic carbon in the Changjiang and Huanghe River estuaries, China: ${ }^{14} \mathrm{C}$ and ${ }^{13} \mathrm{C}$ studies. Limnol. Oceanogr. 61, 1358-1374.

Wang, X.J., Wang, J.P., Shi, H.J., Guo, Y., 2018. Carbon sequestration in arid lands: a mini review. In: Wang, X.J., Yu, Z.T., Wang, J.P., Zhang, J. (Eds.), Carbon Cycle in the Changing Arid Land of China. Springer, Singapore, pp. 133-141.

Wang, X.J., Wang, J.P., Xu, M.G., Zhang, W.J., Fan, T.L., Zhang, J., 2015. Carbon accumulation in arid croplands of northwest China: pedogenic carbonate exceeding organic carbon. Sci. Rep. 5, 11439.

Wang, X.J., Xu, M.G., Wang, J.P., Zhang, W.J., Yang, X.Y., Huang, S.M., Liu, H., 2014. Fertilization enhancing carbon sequestration as carbonate in arid cropland: assessments of long-term experiments in northern China. Plant Soil 380, 89-100.

Washbourne, C.L., Renforth, P., Manning, D.A.C., 2012. Investigating carbonate formation in urban soils as a method for capture and storage of atmospheric carbon. Sci. Total Environ. 431, 166-175.

Xue, C.T., Zhu, X.H., Lin, H.M., 1995. Holocene sedimentary sequence, foraminifera and ostracoda in west coastal lowland of Bohai Sea, China. Quat. Sci. Rev. 14, 521-530.

Zamanian, K., Pustovoytov, K., Kuzyakov, Y., 2016. Pedogenic carbonates: forms and formation processes. Earth Sci. Rev. 157, 1-17. 